\title{
Environmental impact of the typical heavy pig production in Italy
}

Luciana Bava, Maddalena Zucali, Anna Sandrucci*, Alberto Tamburini

Dipartimento di Scienze Agrarie ed Ambientali, Università degli Studi di Milano, Via Celoria 2, 20133 Milano, Italy.

${ }^{*}$ Corresponding author: Dipartimento di Scienze Agrarie ed Ambientali, Università degli Studi di Milano, Via Celoria 2, 20133 Milano, Italy. Tel: + 390250316453 Fax: + 390250316434. E-mail address: anna.sandrucci@unimi.it

\section{ABSTRACT}

The Italian pig sector is mainly focused on the production of heavy pigs used for the traditional drycured hams. At slaughter a minimum of $160 \mathrm{~kg}$ and 9 months age are required to comply with the production specifications of the ham consortia. Advancing livestock age and increasing fat deposition negatively affect feed conversion ratio, which is one of the main determinants of meat production environmental impact. The aim of the study was to provide a first evaluation of the environmental impact potentials of heavy pig production in Italy through a Life Cycle Assessment approach. Additional objectives were to identify the main hot spots and the most important data gaps in the analysis. A cradle to farm gate Life Cycle Assessment was performed in 6 intensive pig farms located in Northern Italy. Key parameters concerning on-farm activities, inputs and outputs were collected through personal interviews to the farmers. The functional unit was $1 \mathrm{~kg}$ liveweight. Direct land use change was considered in the emissions of imported soybean. The average pig slaughter liveweight was $168.7 \pm 33.3 \mathrm{~kg}$. Environmental impacts per $\mathrm{kg}$ liveweight were generally higher than those generated in the production of pigs slaughtered at a lighter weight. The global warming potential was on average $4.25 \pm 1.03 \mathrm{~kg} \mathrm{CO} 2 \mathrm{eq} / \mathrm{kg}$ liveweight. Feed chain (crop production at farm and purchased 
feed) was the major source of impact for all the categories and the most important hotspot of heavy pig production. Farm size and reproductive efficiency are important factors in the environmental burden of heavy pig production: the largest and most efficient farm (as liveweight produced per sow) had impact potentials per kg liveweight much lower than those generated in the less efficient farm and similar to the ones reported on pigs slaughtered at a lower weight. The wide range of impact values within farms reveals opportunities for environmental improvements in the production of the traditional heavy pig. There is a need for further data and models on methane enteric emissions and nitrogen excretions above $100 \mathrm{~kg}$ of liveweight.

\section{HIGHLIGHTS}

- Italian typical dry-cured ham production needs high pig weight and age at slaughter

- Environmental impacts of heavy pig through the Life Cycle approach were assessed

- Data were collected through personal interviews in 6 pig farms located in Northern Italy

- Heavy pigs have impacts of per kg liveweight generally higher than light pigs

- The wide range of impacts within farms reveals opportunities for GHG mitigation

Keywords: heavy pig, environmental impact, Life Cycle Assessment, greenhouse gas emission, drycured ham

\section{Introduction}

The Italian pig sector is primarily focused on the production of heavy pigs, used to provide thighs for dry-cured ham, a traditional processed meat product. Dry-cured ham is a typical food product of many countries worldwide: Spain, Italy, France, Germany, Poland and Greece are the major producers and consumers in Europe (Resano et al., 2011). Currently in Italy there are eight labels of dry-cured ham registered by the European Union as Protected Designations of Origin (PDO); Parma and S. Daniele are the most important labels with a total production of about 11.4 million hams (Consorzio Prosciutto 
di Parma, 2015; Consorzio Prosciutto di S. Daniele, 2015). Overall, approximately 24\% of the production of the two labels is exported, mainly in Europe. For Parma ham the most important European markets are Germany, France and UK while US is the first overseas export market.

According to ERSAF (2014), out of the total $13,100,000$ pigs slaughtered in Italy in $2013,91.2 \%$ had a liveweight (LW) at slaughter higher than $160 \mathrm{~kg}$ and $67.6 \%$ of these heavy pigs were used for the production of PDO dry-cured hams.

For this high quality production, meat with an excellent aptitude for salting and seasoning is required (Bosi and Russo, 2004). In particular, based on PDO specifications, fresh thighs must have a minimum weight of $10 \mathrm{~kg}$ (11 kg for the S. Daniele label). This implies a very high bodyweight (BW) at slaughter $(>160 \mathrm{~kg})$ and a suitable thickness of subcutaneous adipose tissue, at least $15 \mathrm{~mm}$ (Lo Fiego et al., 2005). Moreover, to obtain optimal meat characteristics, heavy pigs have to be slaughtered not before 9 months of age; this condition implies restricted feeding and longer fattening cycles in comparison with production systems adopted in other European countries. Advancing age and increasing BW and fat deposition negatively affect pig feed conversion ratio (Latorre et al., 2003; Malagutti et al., 2012), which is one of the main determinants of meat production environmental impact.

A number of papers analyzed through a LCA approach the environmental impact of the production of pigs slaughtered at a standard LW of 90-120 kg (Basset-Mens and van der Werf, 2005; Dalgaard, 2007; Vergé et al., 2009; Pelletier et al., 2010; Wiedemann et al., 2010; Aramyan et al., 2011; Dourmad et al., 2014; Mackenzie et al., 2015) but studies focusing on the impact evaluation of heavy pig production are presently lacking.

The aim of the study was to provide a first evaluation, throughout a Life Cycle Assessment approach, of the environmental impact potentials of heavy pig production in Italy. Other purposes were to identify hot spots and margins for improvement and to outline the major data gaps in the analysis.

\section{Materials and methods}




\subsection{System description and data collection}

A total of 6 pig farms were involved in the study. They were located in the Po valley (Northern Italy) and their productions were addressed to Parma and San Daniele dry-cured PDO hams. The farms had different production systems: 5 farms were farrow-to-finish and one farm was growth-to-finish (opencycle). All the pigs were crossbred animals complying with PDO rules, reared in intensive indoor systems on slatted-floor or straw litter.

Data collection was performed through personal interviews to the farmers. Information gathered concerned: herd composition and technical data, housing system, slurry management, cropping systems, diets, fuel and electricity consumption, external inputs (purchased feed, fertilizers, pesticides, animals), outputs (sold animals).

\subsection{Emission and excretion estimation}

Methane $\left(\mathrm{CH}_{4}\right)$ emissions from enteric fermentations and slurry management were estimated using the equations suggested by IPCC (2006a; Tier 1 and Tier 2, respectively) following the suggestion of LEAP (2015).

Volatile solid excretion was estimated considering the gross energy of the diets ( $\mathrm{kJ} / \mathrm{kg} \mathrm{DM})$ evaluated using Ewan equation (1989). For the digestibility of the diets the values suggested by IPCC (2006a) for mature $(80 \%)$ and growing swine $(85 \%)$ were used.

From information on ration composition, chemical analysis of the diets and $\mathrm{N}$ and $\mathrm{P}$ excretions were estimated through the model developed by the National Research Council (2012) which considers the BW/physiological phase of the animals and the feed characteristics. The model does not cover the finishing phase above $140 \mathrm{~kg}$ of BW; according to the results of Galassi et al. (2005), from 140 to $170 \mathrm{~kg} \mathrm{BW}$ a reduction of $4 \%$ of $\mathrm{N}$ utilization efficiency compared to the previous phase was assumed and the $\mathrm{N}$ excretions corrected. 
Nitrous oxide $\left(\mathrm{N}_{2} \mathrm{O}\right)$ emissions from slurry storages $\mathrm{N}_{2} \mathrm{O}$ losses from fertilizers and slurry application in direct and indirect forms were both estimated using the Tier 2 method from IPCC (2006a, 2006b). $\mathrm{N}$ applied to the soils from synthetic fertilizers and slurry plus $\mathrm{N}$ from crop residues were accounted in the estimation. Emissions of $\mathrm{CO}_{2}$ from fuel combustion on farm were estimated according to the Agri-footprint v1.0 database (Blonk Consultants, 2014). Emission factors and equations adopted are detailed in Bava et al. (2014).

Ammonia $\left(\mathrm{NH}_{3}\right)$ and nitrogen oxide emissions $(\mathrm{NOx})$ that occur during animal housing and slurry storages were estimated following the method proposed by EEA (2009a) on the basis of the total N excreted by the animals, considering the slurry management systems and the manure type (liquid slurry or solid). $\mathrm{NH}_{3}$ and $\mathrm{NOx}$ emitted during slurry and synthetic fertilizers application to the soils were estimated following EEA guidelines (2009b). For the evaluation of N leached, the IPCC (2006b) model was adopted, while the P lost in dissolved form to surface water (run-off) and leached, was calculated followed Nemecek and Kägi (2007).

The emissions related to off-farm activities were calculated using LCA software, Simapro 8.0.3 (PRé Consultants, 2014). The following processes were considered: production of commercial feed (from crop growing to feed factory), production of bedding material, rearing of purchased animals, production of chemical fertilizers, pesticides, diesel and electricity used at the farms. Transportation was considered only for feed, bedding materials and purchased animals. Mineral feed, vitamins and other feed ingredients used in negligible amounts were not included in the assessment.

A simplified LCA was performed to assess the impacts associated to purchased piglets of $30 \mathrm{~kg} \mathrm{BW}$ in the open-cycle farm: for gestating and lactating sows and for piglets, standard rearing and feeding conditions were considered.

\subsection{Impact assessment}

The environmental impact of pig production in each farm was evaluated through a detailed "cradleto-farm-gate', attributional LCA. The system boundaries included all the on-farm processes plus the 
off-farm activities linked to the production of external inputs without considering slaughtering (Figure 1). System boundaries include also pig slurry that it was used as fertilizer to increase the crops productivity and to maintain organic matter content of soils and represents a direct input for feed production. So these farms can be defined as mixed crop-livestock systems as defined by LEAP (2015).

The selected environmental impact categories were: global warming, eutrophication, acidification, non-renewable energy use, land occupation, abiotic resource depletion, terrestrial ecotoxicity and ozone layer depletion. These evaluations were generally performed using CML-IA baseline 3.01; for non-renewable energy use, the Cumulative Energy Demand 1.08 method was applied, while for land occupation the Ecological Footprint 1.01 method was used.

The functional unit (FU) was established as $1 \mathrm{~kg}$ of $\mathrm{LW}$ at the farm gate. No allocation procedure was applied because the only products sold by the farms were finished heavy pigs and culled sows but the weight of sows yearly sold represented a negligible percentage of total LW sold (0.5-1.3\%).

Figure 1. System boundaries




Direct land use change (LUC) for soybean production in Brazil was considered using the value reported by the Agri-footprint database (Soybean, at farm/BR Economic; Blonk Consultants, 2014). Soybean was assumed as a mix of Brazilian (80\%) and Italian (20\%) products, as reported by Assalzoo (2015).

\section{Results and discussion}

Table 1 reports the main farm characteristics and herd performances of the 6 pig farms. As mentioned above, 5 farms were farrow-to-finish operations while one farm was growth-to-finish. Moreover, 2 farms had large size (more than 15,000 heavy pigs sold per year) while 4 farms had medium size (less than 5,000). Average LW at slaughter was $168.7 \pm 3.33 \mathrm{~kg}$, with an average dressing percentage of $79.2 \pm 0.8 \%$. Technical herd traits show some variability among farms, but on average they are consistent with those reported by BPEX (2014) for Italian swine herds; according to this report, reproductive traits of Italian herds are worse than average performances of EU countries.

Table 1. Herd traits and performances in the six farms under analysis

\begin{tabular}{llcccccc} 
Farm & & $\mathbf{1}$ & $\mathbf{2}$ & $\mathbf{3}$ & $\mathbf{4}$ & $\mathbf{5}$ & $\mathbf{6}$ \\
\hline Cycle & & closed & closed & closed & closed & closed & open \\
Heavy pigs produced & no./year & 30000 & 18895 & 3523 & 3400 & 4900 & 4128 \\
LW* at slaughter & $\mathrm{kg}$ & 169 & 170 & 162 & 170 & 170 & 171 \\
Dressing percentage & $\%$ & 78.0 & 80.0 & 79.5 & 78.4 & 80.0 & 79.0 \\
Sows & no. & 1500 & 925 & 190 & 320 & 405 & \\
Piglets born/sow & no./year & 25.9 & 28.0 & 22.5 & 26.0 & 29.4 & \\
Stillbirths & $\%$ & 1.3 & 1.5 & 2.4 & 4.0 & 4.2 & \\
Piglets weaned/sow & no./year & 22.4 & 26.5 & 20.2 & 22.0 & 25.2 & \\
Weaning age & days & 25 & 21 & 33 & 22.5 & 31 & \\
Litters/sow & no./year & 2.15 & 2.42 & 2.29 & 2.00 & 2.10 & \\
LW* produced/sow & kg/year & 3679 & 3550 & 3134 & 2209 & 2148 & \\
\hline
\end{tabular}

*LW=liveweight 
The average agricultural area of the farms was $198.3 \pm 132$ ha. Most of the farm land was addressed to cereal production (corn, wheat, barley), while only a small area in two farms were sown with soybean; with the exception of one farm, the whole crop productions were used for pig feeding. Feed self-sufficiency in terms of DM was quite low: $17.8 \pm 18.0 \%$ on average, from 0 to $39 \%$.

Diets of finishing pig (100-170 kg) were corn based: the major constituent was corn grain $(28.5 \%$ on DMI on average), followed by wheat bran (13\%), soybean meal $(9.3 \%)$, barley $(9.2 \%)$, wheat middlings (9.2\%), high moisture corn grain $(9.1 \%)$ and other minor components. Finishing pigs were fed restricted liquid diets diluted with milk whey, as suggested by PDO guidelines, or water.

The environmental impact potentials of $1 \mathrm{~kg} \mathrm{LW}$ at farm gate are shown in table 2.

Table 2 - Environmental impact potentials of $1 \mathrm{~kg} \mathrm{LW}$ in the six farms under analysis

\begin{tabular}{llcccccc} 
Farm & & 1 & 2 & 3 & 4 & 5 & 6 \\
\hline Global warming & $\mathrm{kg} \mathrm{CO}_{2}$ eq & 2.69 & 3.73 & 4.50 & 4.22 & 5.81 & 4.58 \\
Eutrophication & $\mathrm{g} \mathrm{PO}_{4}{ }^{\mathrm{eq}}$ & 16.7 & 22.6 & 24.6 & 27.6 & 31.4 & 28.6 \\
Acidification & $\mathrm{g} \mathrm{SO}_{2} \mathrm{eq}$ & 20.0 & 27.7 & 34.4 & 37.1 & 37.9 & 39.2 \\
Non-renewable energy & $\mathrm{MJ}$ & 14.0 & 18.5 & 33.4 & 23.9 & 28.0 & 23.3 \\
Land occupation & $\mathrm{m}^{2}$ & 5.54 & 7.15 & 7.46 & 8.48 & 12.1 & 9.61 \\
Abiotic resource depletion & $\mathrm{g} \mathrm{Sb} \mathrm{eq}$ & 0.003 & 0.004 & 0.005 & 0.005 & 0.005 & 0.005 \\
Terrestrial ecotoxicity & $\mathrm{kg} \mathrm{1.4-DB} \mathrm{eq}$ & 0.026 & 0.006 & 0.007 & 0.006 & 0.008 & 0.006 \\
Ozone layer depletion & $\mathrm{mg} \mathrm{CFC-11} \mathrm{eq}$ & 0.189 & 0.341 & 0.387 & 0.383 & 0.256 & 0.382 \\
\hline
\end{tabular}

The average global warming potential (GWP) was $4.25 \pm 1.03 \mathrm{~kg} \mathrm{CO}_{2}$ eq per $\mathrm{kg} \mathrm{LW}$. As expected, this value is higher than the ones obtained in other studies (table 3) on pigs of lower slaughter weight (Basset-mens and van der Werf, 2005; Dalgaard, 2007; Vergé et al., 2009; Pelletier et al., 2010; Wiedemann et al., 2010; Dourmad et al., 2014; Mackenzie et al., 2015; González -Garcia et al., 2015). Aramyan et al. (2011) assessed GWP per kg LW in a number of European countries: values varied from a minimum of 2.55 to a maximum of $2.97 \mathrm{~kg} \mathrm{CO}_{2}$ eq but pig weights at slaughter were always lower than $120 \mathrm{~kg}$. It is important to underline that in the production of the Italian heavy pig, the 
finishing period is very long because of the minimum slaughter age and weight required by the rules of PDO dry-cured hams. In the last finishing phase the efficiency of feed conversion sensibly decreases, as reported in studies on heavy pigs (Malagutti et al., 2012), and emissions and excretions per kg of LW increase.

Table 3 - Results of GWP of pig production from recent LCA studies (cradle to farm gate)

\begin{tabular}{|c|c|c|c|c|c|c|}
\hline Author & Country & $\mathrm{FU}^{*}$ & $\begin{array}{c}\text { Slaughter } \\
\text { weight }\end{array}$ & $\begin{array}{c}\mathrm{kg} \mathrm{CO} \\
\text { eq/ } / \mathrm{kg} \mathrm{CW}\end{array}$ & $\begin{array}{c}\mathrm{kg} \mathrm{CO}{ }_{2} \\
\mathrm{eq} / \mathrm{kg} \mathrm{LW}\end{array}$ & \\
\hline González -Garcia et al. (2015)** & $\mathrm{P}$ & $\mathrm{CW}$ & 105 & & 2.61 & \\
\hline Dourmad et al. (2014) & EU & LW & 113 & & 2.25 & Conventional \\
\hline Mackenzie et al. (2015) & CND & $\mathrm{CW}$ & 118 & 2.90 & 2.26 & East CND \\
\hline Mackenzie et al. (2015) & CND & $\mathrm{CW}$ & 124 & 2.80 & 2.18 & West CND \\
\hline Nguyen et al.(2010) & EU & $\mathrm{CW}$ & 100 & 4.81 & 3.60 & $W / O L U C$ \\
\hline Nguyen et al.(2010) & EU & $\mathrm{CW}$ & 100 & 9.75 & 7.28 & With LUC \\
\hline Pelletier et al. (2010) & US & LW & 118 & & 2.95 & High profit farms \\
\hline Wiedemann et al.(2010)** & AUS & $\mathrm{CW}$ & 95 & 3.10 & 2.36 & North AUS \\
\hline Wiedemann et al. (2010)** & AUS & $\mathrm{CW}$ & 97 & 5.50 & 4.18 & South AUS \\
\hline Vergé et al. (2009) & CND & LW & & & 2.31 & \\
\hline Dalgaard $(2007)^{* *}$ & DK & $\mathrm{CW}$ & & 3.77 & 2.88 & \\
\hline Basset-Mens, van der Werf (2005) & FR & LW & 113 & & 2.30 & \\
\hline
\end{tabular}

*When original FU was carcass weight (CW), liveweight (LW) was estimated considering an average dressing percentage of $78 \%$ with the exception of Dalgaard, Nguyen et al., Wiedemann et al. who reported a specific dressing percentage: $76.3,75 \%$ and $76 \%$ respectively.

**cradle to slaughterhouse

The variability of GWP per $\mathrm{kg} \mathrm{LW}$ in our results is quite high: from 2.69 to $5.81 \mathrm{~kg} \mathrm{CO}_{2}$ eq. The lower value is similar to the GWP obtained in studies on pigs of lighter slaughter weight; this overlap between the two production systems shows that it is possible to implement mitigation strategies in order to reduce GHG of heavy pig production. In particular, the lower values of GWP were obtained 
in the largest and most efficient farms in terms of LW produced per sow (farm 1); tables 1 and 2 show that GWP tends to linearly increase as LW sold per sow decreases. Farm 5, which had the lowest LW sold per sow and was also quite small in terms of size, registered the highest GWP, almost twice the one of the most efficient farm. This result shows the positive effect of large farm size and high reproductive efficiency in reducing GHG emissions per $\mathrm{kg} \mathrm{LW}$, as a consequence of both scale economies in using energy and dilution of environmental impact of sows on a higher LW produced per sow. In Italy reproduction performances are low in comparison with other EU countries and average farm size is increasing but still small (BPEX, 2014); some opportunities exist for improving efficiency and environmental performances. This result suggests also a tendency towards a positive relationship between environmental performances and profitability; similarly Pelletier et al. (2010) noted that high-profitability operations have consistently lower impacts compared to low-profitability operations.

As reported in many studies (Basset-Mens and van der Werf, 2005; Dalgaard, 2007; Dourmad et al., 2014; González-García et al., 2015), feed chain (on-farm production and purchase) was the first source of GHG for pig production contributing for over $70 \%$ of total GWP; in particular purchased feed alone contributed for $58.1 \pm 10.5 \%$ (Figure 2).

The main GWP contributing gases were $\mathrm{CO}_{2}(59.4 \%), \mathrm{N}_{2} \mathrm{O}(22.6 \%)$ and $\mathrm{CH}_{4}(17.9 \%)$. In particular, the contribution to GWP of $\mathrm{CO}_{2}$ generated by land use change (LUC) for soybean was $23.5 \pm 9.95 \%$. LUC accounts for a large amount of $\mathrm{CO}_{2}$ emissions in animal feed supply chain, particularly in relation to the use of imported soybean from South America. However, to date there is not a standardized and widely accepted approach in LCA studies to quantify the emissions related to LUC (Sasu-Boakye, et al., 2014) and most of the studies on meat and pork production do not consider LUC. According to Dalgaard (2007) the GWP per kg of soybean meal increases dramatically from 0.7 to $5.7 \mathrm{~kg} \mathrm{CO}_{2}$ eq if the carbon released due to LUC is included in the estimation. Excluding LUC from the estimation of GWP the difference between GWP of heavy pig production chain and standard light pig becomes very small. This result confirms that GWP of livestock productions, particularly in 
monogastrics, is greatly affected by the LUC accounting method; it also underlines the need of defining a standard widely accepted approach for LUC assessment in LCA studies on environmental impact of livestock.

Figure 2. Contributions of different activities to environmental impact categories

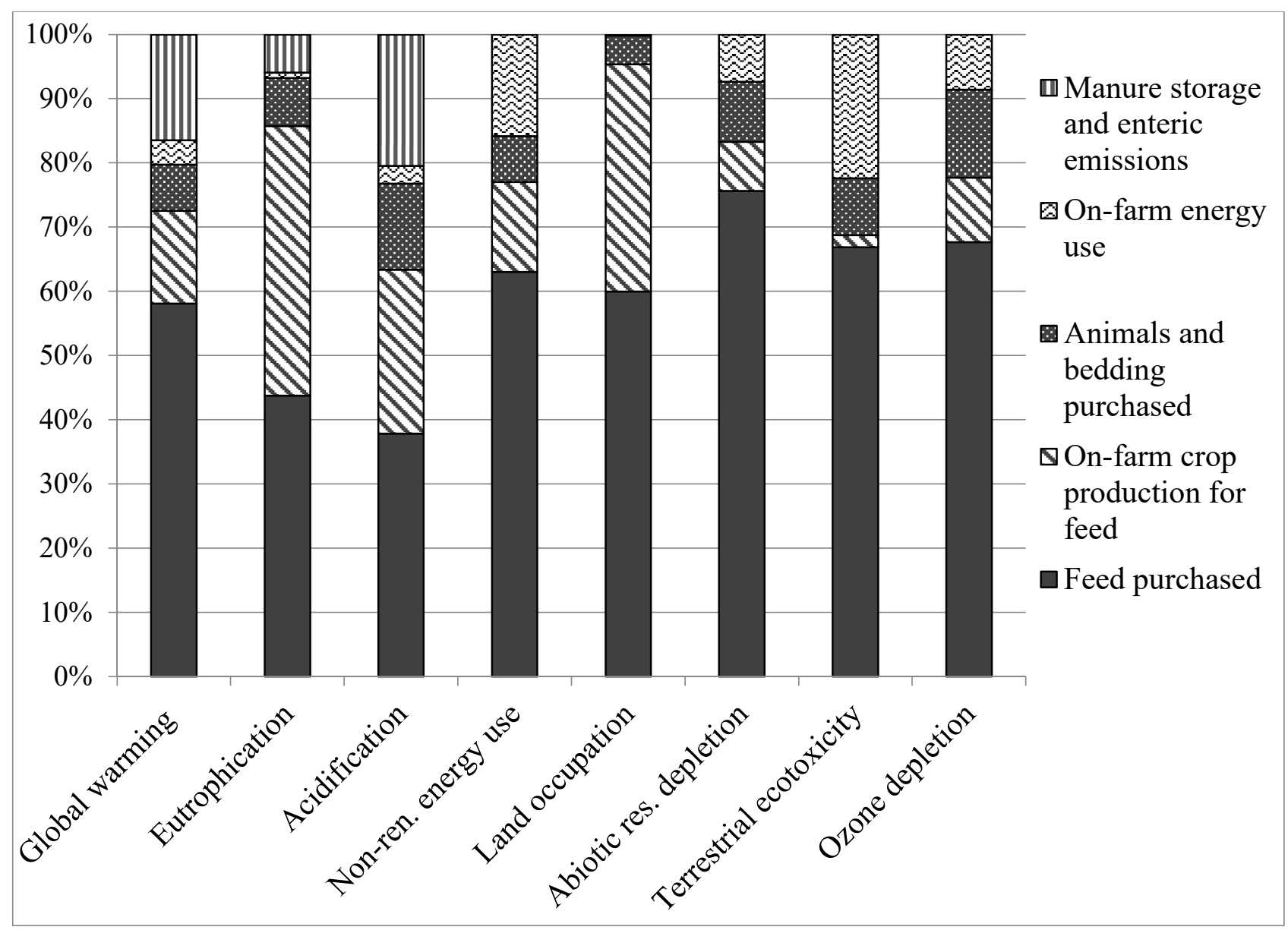

To reduce the effect of imported soybean on GHG emission of pork chain, the evaluation of protein sources grown locally could be proposed as suggested by Cederberg and Flysio (2004). According to Sasu-Boakye et al. (2014) local protein feed production presents an opportunity to reduce GHG emissions by about $4.5 \%$ for pigs. At the moment PDO ham specifications represent an obstacle to change because the protein feed admitted in the diet of finishing pigs ( $>80 \mathrm{~kg} \mathrm{BW})$ are very few in order to avoid the potential transfer of undesired flavors to the ham. 
The second important contribution to GW impact category was generated by housing and slurry storages that represented $3.77 \pm 0.62 \%$ and $12.69 \pm 3.97 \%$, respectively. Besides slurry emissions, housing included enteric emissions, which are very small in monogastrics in comparison to ruminants. In this study the fixed value of enteric emission of $\mathrm{CH}_{4}$ suggested by Ecoinvent Tier 1 was adopted and the contribution of enteric $\mathrm{CH}_{4}$ to GWP was only $0.07 \%$. However, it is likely that the heavy pigs may have higher $\mathrm{CH}_{4}$ production than lighter pigs; according to Jørgensen et al. (2011) the general trend is an increase in $\mathrm{CH}_{4}$ emission in response to increasing $\mathrm{BW}$.

Eutrophication potential (EP) was on average $25.2 \pm 5.19 \mathrm{~g} \mathrm{PO}_{4}{ }^{3}$ eq emitted per $\mathrm{kg} \mathrm{LW}$; feed production both on-farm and off-farm was the main contributor of this category $(85.7 \%)$. Our EP is similar or slightly higher than the findings of other researchers on pigs of lighter slaughter weight (Basset Mens and van der Werf, 2005; Dalgaard, 2007; Reckmann et al., 2013; Dourmad et al., 2014; Mackenzie et al., 2015). Nitrate and phosphate released in water and ammonia emitted in the air contributed respectively for $64 \%, 21 \%$ and $5 \%$ to EP.

Acidification potential (AP) was on average $32.7 \pm 7.47 \mathrm{~g} \mathrm{SO}_{2} \mathrm{eq} / \mathrm{kg} \mathrm{LW}$; the main source was feed production (both purchased and grown at farm) that contributed for $63.4 \%$, followed by slurry and enteric emissions (20.5\%). As expected, ammonia was the main responsible $(75.8 \pm 4.62 \%)$ of AP, followed by nitrogen oxides $(12.0 \pm 1.62 \%)$. In this study average AP is between the extreme values reported by Basset-Mens and van der Werf (2005) for different pig production chains in France. However. our AP are generally lower than those found by other authors (Dalgaard, 2007; Reckmann et al., 2013; Dourmad et al., 2014; Mackenzie et al., 2014) probably for the different methodologies applied for AP estimation and $\mathrm{N}$ and $\mathrm{P}$ excretions evaluation.

According to Dalgaard (2007), among the substances with the highest potential impact there are: nitrous oxide for GWP, nitrate and ammonia for EP and ammonia again for AP. As these are all N compounds, a more efficient use of $\mathrm{N}$ from swine could improve environmental performances. Some studies on traditional heavy pig showed the feasibility of a reduction of $\mathrm{N}$ excretion by decreasing the 
dietary protein level and optimizing the aminoacid profile in the different physiological phases (Xiccato et al., 2005).

The non-renewable energy use per kg LW was on average $23.5 \pm 6.84 \mathrm{MJ}$ and the lower values were obtained in the largest farms. The results are comparable but slightly higher than those reported on lighter pigs (Basset-Mens \& van der Werf, 2005; Dourmad et al., 2014; Mackenzie et al., 2015). The main use of energy was related to the production of purchased feed $(63.0 \pm 14.7 \%)$.

Land occupation was on average $8.39 \pm 2.28 \mathrm{~m}^{2}$ per $\mathrm{kg} \mathrm{LW}$. Our results are slightly higher but comparable to the findings of Basset-Mens and van der Werf (2005) but much higher than the values reported by Dourmad et al. (2014) and by González-García et al. (2015).

Abiotic resource depletion potential estimates the extraction of scarce minerals. In our study it was on average $0.004 \pm 0.00008 \mathrm{~g} \mathrm{SB}$ eq per $\mathrm{kg} \mathrm{LW}$, much lower than the result reported by Mackenzie et al. (2014). As obtained by Mackenzie et al. (2015), the major contribution is generated by the production of purchased feed $(83.3 \%)$.

Terrestrial ecotoxicity refers to the impacts of toxic substances on terrestrial ecosystems. Per kg LW, terrestrial toxicity varied from 0.0055 to $0.0255 \mathrm{~kg} 1.4$-DB eq. with an average value of 0.009 . Our results are lower than those reported by Basset-Mens and van der Werf (2005) and by González Garcia et al. (2015). Production of feed was the main source of terrestrial ecotoxicity (68.7\%).

The ozone depletion estimates the destruction of the stratospheric ozone layer by anthropogenic emissions of ozone-depleting substances. In this study the ozone depletion potential was on average $0.323 \pm 0.08$ mg CFC-11 eq per kg LW. As obtained by González -Garcia et al. (2015), feed component production is the main contributor in this category $(77.7 \%)$.

In accordance with the conclusion of González-García et al. (2015), feed production (both on-farm and off-farm) was the main contributor to all the impact categories analysed, ranging from $63 \%$ to $95 \%$.

Figure 3 illustrates the contributions to the environmental impact categories of different physiological phases: breeding (gestating and lactating sows plus sucking piglets); weaners (from weaning to $50 \mathrm{~kg}$ 
BW); growing pigs (50-100 kg BW); finishing pigs (100-170 kg BW). These percentages were calculated on farm where it was possible to obtain a precise attribution of consumptions and emissions related to the different phases. The breeding phase contributes for $11.3 \%$ to GWP per $\mathrm{kg}$ LW produced. Similar contributions were estimated by Thoma et al. (2011) and Mackenzie et al. (2015). The contributions of breeding phase to AP and energy use were $13.6 \%$ and $12.3 \%$, respectively, similar to the values obtained by Mackenzie et al. (2015). The environmental burden of the finishing phase was about $26 \%$ for all impact categories.

Figure 3. Contributions of different physiological phases to environmental impact categories

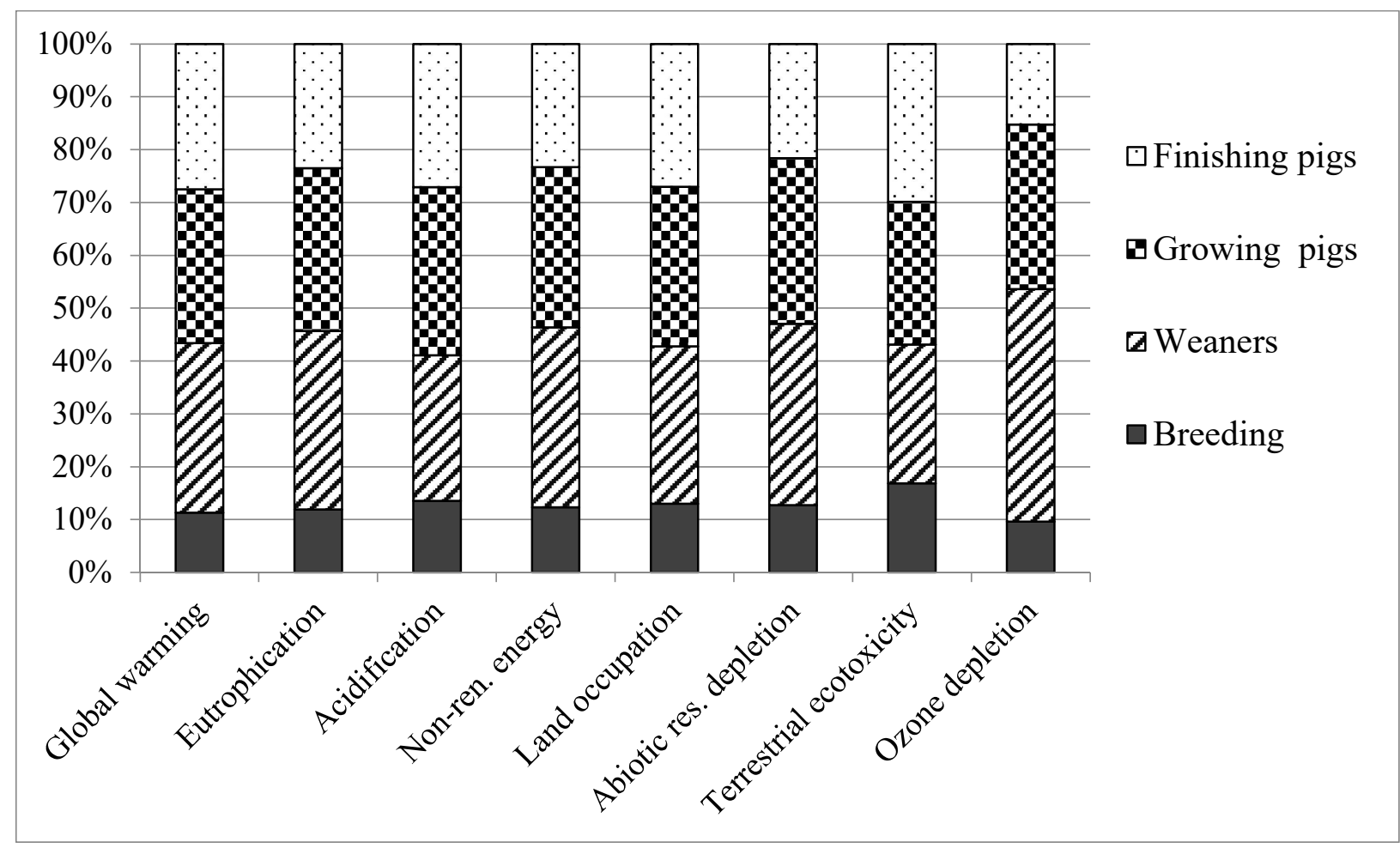

\section{Conclusions}

This study provides the first quantification through a LCA approach of environmental impacts of the heavy pig production, which covers a traditional and significant part of Italian meat production. Results show that the production of heavy pigs generated environmental impacts per kg LW generally higher than the production of standard pigs slaughtered at lighter weight. The differences are 
particularly important for GWP but the results of this study are worsened by the inclusion of direct LUC for soybean in the GHG estimation. As GWP of livestock production (especially monogastric) is greatly affected by LUC assessment there is a need for defining a standard and widely accepted LUC accounting method in LCA studies on animal productions. The use of local protein sources instead of soybean is limited by the PDO ham specifications.

The study confirms the important role of feed chain in the environmental load of pork production as underlined by many authors: feed components are the main contributors to all the impact categories. In particular, as substances contributing to the main impacts are in many cases $\mathrm{N}$ compounds, a more efficient use of $\mathrm{N}$ from swine through decreasing the dietary protein level and optimizing the aminoacid profile on the basis of the physiological phase, will improve the environmental performances of heavy pig production. Further researchers on heavy pig have to be implemented to study this topic.

Farm size and reproductive efficiency are important factors for the mitigation of the environmental impact of heavy pig production: in the sample analysed, the largest and most efficient farm (in terms of LW sold per sow) had impact potentials per kg LW much lower than those generated in the less efficient farm.

Among the major data gaps that negatively affect environmental impact assessment of heavy pig production are the scarcity, or sometimes the complete absence, of in vivo measures and models for the estimations of enteric $\mathrm{CH}_{4}$ emission and $\mathrm{N}$ excretion in the finishing phase, above $100 \mathrm{~kg}$ of liveweight.

\section{Acknowledgements}

The authors would like to thank the farmers who have made available data on their herds for the analysis

\section{References}


Aramyan, L.H., Hoste, R., van den Broek, W., Groot, J., Soethoudt, H., Nguyen, T. L., Hermansen, J.E., van der Vorst, J. , 2011. Towards sustainable food production: a scenario study of the European pork sector. Journal on Chain and Network Science, 11(2), 177-189.

Assalzoo (Associazione Nazionale tra i Produttori di Alimenti Zootecnici), 2015. Audizione in Senato, Commissione Agricoltura E Produzione Agroalimentare. https://www.senato.it/application/xmanager/projects/leg17/attachments/documento_evento_ procedura_commissione/files/000/002/860/ASSALZOO_nota_informativa.pdf. Accessed September 2015

Basset-Mens, C., van der Werf, H.M.G., 2005. Scenario-based environmental assessment of farming systems: the case of pig production in France. Agr. Ecosyst. Environ. 105, 127-144.

Bava, L., Sandrucci, A., Zucali, M., Guerci, M., Tamburini, A., 2014. How can farming intensification affect the environmental impact of milk production? J. Dairy Sci., 97(7), 45794593.

Blonk Consultants, 2014. Agri-footprint database. http://www.agri-footprint.com/

Bosi, P., Russo, V., 2004. The production of the heavy pig for high quality processed products. Ital. J. Anim. Sci, 3, 309-321.

BPEX (2014). 2013 pig cost of production in selected countries. C) Agriculture and Horticulture Development Board 2014

Cederberg, C., Flysjö, A., 2004. Environmental assessment of future pig farming systems. Quantifications of Three Scenarios from the Food, 21, 1-54.

http://pork.ahdb.org.uk/media/2371/2013_pig_cost_of_production_in_selected_countries.pdf

Consorzio Prosciutto di Parma 2015. Accessed July 2015.

http://www.prosciuttodiparma.com/it IT/consorzio

Consorzio Prosciutto di S. Daniele 2015. Accessed July 2015.http://www.prosciuttosandaniele.it/ 
Dalgaard, R., 2007. The environmental impact of pork production from a life cycle perspective. Doctoral dissertation, Aalborg University, The Faculty of Engineering and Science, Department of Development and Planning.

Dourmad, J. Y., Ryschawy, J., Trousson, T., Bonneau, M., Gonzàlez, J., Houwers, H. W. J., Hviid, M., Zimmer, C., Nguyen, T. L.T., Morgensen, L., 2014. Evaluating environmental impacts of contrasting pig farming systems with life cycle assessment. Animal, 8(12), 2027-2037.

EEA, 2009a. EEA (European Environment Agency). 4.B Animal husbandry and manure management GB2009 update. From the EMEP/EEA air pollutant emission inventory guidebook 2009.

EEA, 2009b. EEA (European Environment Agency). 4.D Crop production and agricultural soils. From the EMEP/EEA air pollutant emission inventory guidebook 2009.

ERSAF - Ente Regionale Servizi all'Agricoltura e alle Foreste, 2014. Osservatorio Agroalimentare Lombardo - Il mercato dei suini, produzione e consumo. Quaderno $\mathrm{n}^{\circ} 23$, edizione maggio 2014.

Galassi, G., Crovetto, G. M., Rapetti, L., 2005. Trend of energy and nitrogen utilization of high fibre diets in pigs from 100 to $160 \mathrm{~kg}$ bodyweight. Ital. J. Anim. Sci., 4(2), 149-157

Gerber, P.J., Steinfeld, H., Henderson, B., Mottet, A., Opio, C., Dijkman, J., Falcucci, A., Tempio, G., 2013. Tackling climate change through livestock - A global assessment of emissions and mitigation opportunities. Food and Agriculture Organization of the United Nations (FAO), Rome.

González-García, S., Belo, S., Dias, A. C., Rodrigues, J. V., da Costa, R. R., Ferreira, A., Pinto de Andrade, L. , Arroja, L., 2015. Life cycle assessment of pigmeat production: Portuguese case study and proposal of improvement options. J. Clean. Prod., 100, 126-139.

Guinée, J. B., 2002. Handbook on life cycle assessment operational guide to the ISO standards. The international journal of life cycle assessment, 7(5), 311-313.

IPCC, 2006a. IPCC Guidelines for National Greenhouse Gas Inventories. In: Agriculture, Forestry and Other Land Use, vol. 4, pp. 1-87 Chapter 10: Emissions from livestock and manure 
management. Prepared by the National Greenhouse Gas Inventories Programme, Eggleston H.S., Buendia L., Miwa K., Ngara T. and Tanabe K. (eds). Published: IGES, Japan.

IPCC, 2006b. IPCC Guidelines for National Greenhouse Gas Inventories. In: Agriculture, Forestry and Other Land Use, vol. 4, pp. 1-54 Chapter 11: $\mathrm{N}_{2} \mathrm{O}$ emissions from managed soils, and CO2 emissions from lime and urea application. Prepared by the National Greenhouse Gas Inventories Programme, Eggleston H.S., Buendia L., Miwa K., Ngara T. and Tanabe K. (eds). Published: IGES, Japan.

Jørgensen, H., Knudsen, K. E. B., \& Theil, P. K., 2011. Enteric methane emission from pigs. INTECH Open Access Publisher. Accessed July 2015.

http://cdn.intechweb.org/pdfs/21135.pdf

LEAP, 2015. Environmental performance of large ruminant supply chains: Guidelines for assessment. Draft for public review. Livestock Environmental Assessment and Performance (LEAP) Partnership. FAO, Rome, Italy.

Latorre, M. A., Medel, P., Fuentetaja, A., Lázaro, R., \& Mateos, G. G., 2003. Effect of gender, terminal sire line and age at slaughter on performance, carcass characteristics and meat quality of heavy pigs. Animal Science-Glasgow Then Penicuik, 77(1), 33-46.

Lo Fiego, D. L., Santoro, P., Macchioni, P., De Leonibus, E., 2005. Influence of genetic type, live weight at slaughter and carcass fatness on fatty acid composition of subcutaneous adipose tissue of raw ham in the heavy pig. Meat Sci., 69(1), 107-114.

MacLeod, M., Gerber, P., Mottet, A., Tempio, G., Falcucci, A., Opio, C., Vellinga, T., Henderson, B., Steinfeld, H., 2013. Greenhouse gas emissions from pig and chicken supply chains - A global life cycle assessment. Food and Agriculture Organization of the United Nations (FAO), Rome.

Malagutti, L., Colombini, S., Pirondini, M., Crovetto, G. M., Rapetti, L., Galassi, G., 2012. Effects of phytase on growth and slaughter performance, digestibility and nitrogen and mineral balance in heavy pigs. Ital. J. Anim. Sci.,11(4), 70. 
Mackenzie SG, Leinonen I, Ferguson N, Kyriazakis I. 2015 Accounting for uncertainty in the quantification of the environmental impacts of Canadian pig farming systems. J. Anim. Sci. 2015 Jun;93(6):3130-43.

National Research Council, 2012. Nutrient Requirements of Swine. Eleventh revised edition. National Academy Press, USA

Nemecek, T., Kägi, T., 2007. Life Cycle Inventories of Swiss and European Agricultural Production Systems. Final Report Ecoinvent V2.0 No. 15a. Agroscope Reckenholz-Taenikon Research Station ART, Swiss Centre for Life Cycle Inventories, Zurich and Dübendorf, CH. In: SimaPro PhD 7.3.3/Database/Professional/Ecoinvent

Nguyen, T. L. T., Hermansen, J. E., \& Mogensen, L., 2010. Fossil energy and GHG saving potentials of pig farming in the EU. Energy Policy, 38(5), 2561-2571.

Pelletier, N., Lammers, P., Stender, D., Pirog, R., 2010. Life cycle assessment of high-and lowprofitability commodity and deep-bedded niche swine production systems in the Upper Midwestern United States. Agric. Syst., 103(9), 599-608.

PRé Consultants. 2014. SimaPro (8.0.3.), LCA software. Amersfoort, the Netherlands. Accessed January 2015. http://www.pre.nl.

Reckmann, K., Traulsen, I., Krieter, J., 2013. Life Cycle Assessment of pork production: A data inventory for the case of Germany. Livest. Sci., 157(2), 586-596.

Resano, H., Perez-Cueto, F. J., Sanjuán, A. I., de Barcellos, M. D., Grunert, K. G., Verbeke, W., 2011. Consumer satisfaction with dry-cured ham in five European countries. Meat Sci., 87(4), 336-343.

Sasu-Boakye, Y., Cederberg, C., Wirsenius, S., 2014. Localising livestock protein feed production and the impact on land use and greenhouse gas emissions. Animal, 8(08), 1339-1348.

Thoma, G., Martin, R. E., Nutter, D., Ulrich, R., Martin, R. E., Maxwell, C., Frank , J., East, C., 2011. National life cycle carbon footprint study for production of US swine. National Pork Board, Des Moines, IA. 
Van der Werf, H. M., Petit, J., Sanders, J., 2005. The environmental impacts of the production of concentrated feed: the case of pig feed in Bretagne. Agric. Syst., 83(2), 153-177.

Vergé, X. P. C., Dyer, J. A., Desjardins, R. L., Worth, D., 2009. Greenhouse gas emissions from the Canadian pork industry. Livest. Sci., 121(1), 92-101.

Xiccato, G., Schiavon, S., Gallo, L., Bailoni, L., Bittante, G., 2005. Nitrogen excretion in dairy cow, beef and veal cattle, pig, and rabbit farms in Northern Italy. Ital.J.Anim.Sci., 4 (suppl..3), 103111.

Wiedemann, S., McGahan, E., Grist, S., Grant, T., 2010. Environmental assessment of two pork supply chains using Life Cycle Assessment. Rural Industries Research and Development Corporation: Canberra 